\title{
Youth Off-Script: Unleashing the Life Stories and Hopes of the Out-of School-Youths
}

\author{
Lauro Aspiras ${ }^{1}$ and Emma Aspiras \\ Quirino State University, Cabarroguis Campus, Philippines
}

\begin{abstract}
This study utilized the narrative inquiry and phenomenological research design. This inquiry aimed to explore and capture the eidetic life stories and hopes of the Out-of-School Youths. A total of five participants who were selected applying the chain-referral sampling took part in an individual open-ended and in-depth interview. The narratives of the participants were categorized into three. The first category is their life stories during their stay in School. It was noted that four themes emerged in this category, such as (1) struggle to live and to survive, (2) push, pull, and fall out, (3) Bully, bullied: Blended (4) low, lone, and leave. This study also highlighted the life stories of the participants after they dropped out of school. There were two themes generated: (1) Home, Haze, and bored; (2) easy go lucky. Moreover, the study also highlighted the hopes of the participants, and three themes appeared such as (1) hope for education and employment, (2) hope for the revival of their sense of pride and self-esteem, and (3) hope for support and assistance. Likewise, the researchers came up with initiatives to answer the hopes of the participants, to wit: (1) organization of Parent Teachers Association, (2) collaboration with the PSWD, DTI, and TESDA (3) collaborative extension programs between and among the different departments of the university.
\end{abstract}

KEYWORDS: Collaboration, Extension Program, Hopes, Life Stories, Out-of-School Youth.

Why youth off-script? What is our interest in this topic? What is our investment in this project? Lexicom.com (2020) defined "off- script" as a manner that deviates from or does not use the given script. Conversely, youth off-script is operationally defined in this paper as students deviating or disengaging from the school activities or simply dropped from school. Hence, this study focused on the life stories of the Out-of-School Youths (OSYs) and as teachers and parents of two teenagers, we are confronted with different challenges specifically in handling situations where our teen children and our students are involved. We believe that awareness and experiences cannot be explained by simply theories and systems of ideas but definitely with real stories (James, 2018; Damgaci \& Aydin, 2018; Riessman, 2010), and thus the inquiry was conceptualized. As such, we came up with this inquiry to have a deeper understanding of their aspirations and behavior by lensing their experiences. Moreover, we had learned through a literature search that there were no studies undertaken in the province of Quirino, Philippines focusing on the experiences of the OSY nor using narrative inquiry as a methodology to do so. Concomitantly, there were many studies in the Philippines (e.g.Laya et al, 2017; Machica \& Machica, 2017; Albert et al, 2012) but only a few are using qualitative inquiry. Moreover, the narrative inquiry we highlighted is filled with uncertainty, the uncertainty that comes with not knowing and with the opening up of self to inquire into felt tensions (Clandinin, 2010). This led us to our 'research enigma', to explore the OSY's

\footnotetext{
${ }^{1}$ Correspondent Author E-Mail: lauro.aspiras@qsu.edu.ph
} 
experiences in any way mirrored significant transition of empirical context from a "part of the script" (during their schooling) to "off-script" (dropped out from school). Further, we also wanted to go beyond that and find out how they coped with both their specific experiences of transition. Thus, to execute this, we needed to come up with a vivid and composite picture of the issue in focus' (James, 2018; Benson, 2014), which narrative inquiry enables. Data collected consisted primarily of in-depth research interview and casual conversations, in which we attempted to follow 'participants down their trails' (Riessman, 2008), a more narrative style of interviewing which demands not 'right' data but rather 'different' data (James, 2018). Concurrently, we noted down these conversations along with our thoughts and reflections and ensured that they were made visible throughout our research writing. This was a novel approach for us, not having used narrative inquiry in any previous research we had undertaken.

Hence, it is on the above premises that this study was abstracted. It is generally intended to further investigate the stories behind the phenomenon through the narratives of the participants. It specifically aimed to explore the life stories and hopes of the Out-of-School Youths. Henceforth, the insights gained from this study could be a benchmark in initiating interventions on how to minimize or prevent dropouts in the university. This could also be a basis in coming up with a comprehensive and sustainable extension/outreach program of the university for the out-of-school youths.

\section{Literature Review}

In recent years, education has been placed at the center of the global development agenda, reflecting its recognition as an essential condition for human development, poverty reduction, and economic growth. Understanding the nature of student disengagement helps frame an investigation of which dropout prevention programs are effectively re-engaging students. According to Johnson (2013), what is needed are effective, systemic reforms to improve a school's holding power. Characteristics of schools with the greatest holding power include small enrollment, fair discipline policies, caring teachers, high expectations, and opportunities for meaningful participation (Christenson \& Thurlow, 2004; Demir \& Akman, 2015).

Furthermore, according to information assimilated from a comprehensive review of federal dropout-prevention evaluations, characteristics that lowered dropout rates included: smaller class sizes, more personalized settings, and individualized learning plans (Gleason \& Dynarski, 2009). As a result of their longitudinal study, Shernoff et al (2003) suggested, "Activities that are academically intense and foster positive emotions stand the best chance of engaging students" (p. 173).

Undeniably, the problem of school dropout remains a serious issue in the academe. Every year, many students attend high school and college, but many of them often fail or drop out within less than three years (Tudy et al, 2017). These dropouts seemed to be forgotten by the schools or consciously ignored. It was assumed that if a student is not doing well and is a problem, it's easier to let them slip away.

Currently, according to the UNESCO Institute of Statistics (2018) for the school year ending in 2017 about 262 million children and youth are out of school. The total includes 64 million children of primary school age, 61 millions of lower secondary school age, and 138 millions of upper secondary age. Moreover, according to the results of the 2016 Annual Poverty Indicators Survey (APIS), almost ten percent of the estimated 39 million Filipinos 6 to 24 years old were out-of-school children and youth (OSCY).

On the other hand, according to the Provincial Advisory Council (2017) and the Municipal Advisory Councils of the six towns of Quirino province (Diffun, Cabarroguis, Aglipay, Saguday, Maddela, and Nagtipunan), they are currently getting and analyzing the profiles of the eight hundred twenty-six out-of-school youth to bring them back to school. 
According to the initial report of the Provincial Pantawid Pamilya office, the reasons why the youth quitted school are as follows: they are already working to help their family, disinterest in studying, teenage pregnancy, financial problem, disability, and sickness. Thus, the problems that result from this assumed not only the problems of the dropped-out children, but they could lead to other bigger issues, such as crime and labor skills problems as well. (Naew Na, 2012).

Likewise, based on the data provided by the Office of the Guidance Counselor of Quirino State University, Cabarroguis Campus, there is a gradual decrease in the number of dropouts in the campus from the school year 2015-2016 to 2017-2018. The data show that from 04.88 percent of dropout in 2016-2017 it decreases to 01.92 percent in 2017-2018. Further, according to the report, the main reasons for dropping out of the university are financial constraints and family-related cases.

Indeed, while considerable research exists substantiating the statistics for this societal predicament, studies that seek to uncover the individual human story behind this dilemma are still needed. Research studies like this one are emerging to unravel the stories that lead to an individual's decision to engage or not engage with their high school or college education.

Dropping out from school continues to be a phenomenon in Philippine education even though every year the government through school authorities dovetails efforts to drumbeat the importance of education in human life (Machica \& Machica., 2017).

Research has highlighted the relationship between school dropout and criminal behavior including violence, assault, and drug-related crime. Of particular relevance to this study, numerous studies suggest that individuals who drop out of high school may face a higher risk for problems related to the use of tobacco, alcohol, marijuana, and other illicit drugs (Maynard et al, 2015).

The factors identified under personal-related cluster include but not limited to: cognitive and non-cognitive characteristics of students (persistence, motivation, self-esteem), entering adolescence, which involves a complex redefinition of their personalities, student's anxiety depression, and will, that includes personal choice and decision to leave school (Valkoy, 2018).

On the other hand, most students go to college with the hope of giving themselves the foundation that they need to be successful in life or the skill that they need to find a good job. Every year, many students attend college, but some of them often fail or drop out within less than three years. Dropping out is a serious problem because it denies individual students their fundamental human right to education (Tudy, 2014).

As could be observed anywhere in the countryside, these OSY are always the successors of the throne of poverty bequeathed to them by their parents or guardians. They may be interested in finishing formal schooling yet poverty forces them to leave out school (Tafere, 2015). Quitting from school before earning a high school diploma makes disadvantaged young people unprepared for the world of work and makes them the subject of high risk of poverty. Some students quit because of problems with a certain subject, some because of pregnancy, and others because they must work to support their family (Fernandez \& Abocejo, 2014).

School-related factors such as high level of racial or ethnic discrimination of students, school phobia, school violence, conflicts (with teachers, peers), negative attitude of the teachers, failure in individual subjects, low motivation of certain teachers to interact with students, poor quality of teaching, the deficit of learning and emotional support, and lack of positive teacher-student relationships ( Teneva, 2018; Simic \& Krstic, 2017) are among the main causes for dropping out of school.

Community-related factors for school dropout consist of living in rural areas, especially in small and remote localities, unemployment among the adults in the family, leading to unsatisfactory social, and housing conditions, the limited cultural and educational opportunities, as well as the lack of convenient transportation. Marginalized urban neighborhoods also generate conditions that can lead to school dropout (Lavrentsova \& Valkov, 2017). 
Traveling long distances to schools was causing some children to drop out of school. This is because young adult girls who cannot afford transportation costs are reluctant to walk a long distance to schools. After all, safety and cultural issues prevailed in the remote rural areas (Mughal \& Aldridge, 2017). Similarly, poor boys will also suffer if middle and high schools are far from a village and it is not possible to access them on foot.

The widespread problem of malnutrition puts children at risk of underperforming and undermines their mental and physical growth. Furthermore, Bhutta (2017) described the problem of malnutrition as leading to absenteeism and dropout.

On the other hand, this study also focused on the four theories such as McClelland's learned need theory; expectancy-value theory; scarcity of resources theory; and selfdetermination theory. Thus, the context of the participants' life stories and hopes is framed in the theories mentioned. Machica et al (2017) in their Learned Needs Theory had categorized the needs of a person into three which are the following: (a) need for achievement, (b) need for affiliation, (c) and need for power. These needs serve as the basis for behavior and motivation. Deduced from the theory, it is from any of these needs that an Out of School Youth (OSY) will take the reference as motivators in setting and achieving his goal or hopes in life. A similar view is held by the Expectancy Value Theory of Atkinson, Fishbein, Eccles, Wigfield, and Wigfield, and Tonks, Chauncey (2000), which described that a person is goal-oriented and the behavior that a person performs in response to his/her beliefs and values are undertaken to achieve a goal or purpose. Accordingly, an OSY orients himself or herself to the world according to expectations and evaluations. His/her behavior, behavioral intentions, or attitudes are seen as a function of expectancy (or belief) which is the perceived probability that a goal or object possesses a particular attribute or that behavior will have a particular result; and evaluation, which is the degree of positive or negative effect toward an attribute or behavioral outcome. Further, attainment of aspirations of the OSY is likewise held in the Theory of SelfDetermination of Deci \& Ryan (2008), and Tran (2014) when they said that a person must be in control of one's own life, interact effectively with the environment, and form connections and relationships, and the kind of motivation for the fulfillment of one's need or priority can either be internal or external to the self that initiates, presses or coerces one's action. If the OSY has a high internal perceived locus of causality, he or she feels to be the initiator and sustainer of his actions and is self-determined because his or her behavior stems from his own choices or priority. On the other hand, when the OSY has an external perceived locus of causality, he or she considers behavior as being controlled by some external event, person, or force. It is thus interesting to discover this perceived locus of causality about achieving the aspirations of the OSY.

To sum up, our research on the lived experiences of the OSYs was grounded on the transitions of their experiences particularly when they are "on-script" (during their stay in school) and "off-script" (dropped out from school).

\section{Methods}

\section{Research Design}

This study utilized the qualitative approach to obtain empirical data. It specifically employed the narrative inquiry and phenomenological research design. Thus, a qualitative study investigates meanings and personal experiences constructed by individuals in a particular setting. Hatch (2002) stated, "For qualitative researchers, the lived experiences of real people in real settings are the objects of the study" (p. 6). As Klassen et al (2012) affirmed, one characteristic of qualitative research is to develop a deep "detailed understanding of a central phenomenon" (p. 16). Also, Lichtman (2011) pointed out that, "The main purpose of qualitative research - whatever kind - is to provide an in-depth description and understanding of the human 
experience .. . human phenomena, human interaction, or human discourse" (p. 8). The constructions are „unique ee as pointed out by Creswell \& Poth (2017); Merriam \& Tisdell, (2015); and Freebody (2003) in their treatises of qualitative research methods.

On the other hand, according to Clandinin (2006), a narrative-based approach enables understanding how a social and a personal experience gradually intertwines as people's lives advance. Creswell (2007) explained that the implementation of narrative inquiry involves studying one or more individuals in which the collection of stories as data are rigorously employed for analysis, individual reporting, and chronological ordering of those experiences. He explained further that using narrative inquiry as a design allows the researcher to act as a discreet facilitator for the participant to speak of her experiences freely without interruptions.

Moreover, phenomenology, according to Manen (2014), aimed at looking straight at the core of the phenomenon, describing and analyzing the instantaneous experiences of people who have been exposed to such phenomena.

Hence, phenomenology and narrative inquiry are appropriate for this study considering that the researcher wanted to present vividly the Out of School Youth's life stories (Franzosi, 2010) and looking at the phenomenon intensely.

\section{Sampling and Setting}

The participants of the study were the 5 Out of School Youth (OSYs) in the municipality of Cabarroguis, Quirino, Philippines. They were chosen using non-probability sampling specifically chain-referral sampling. In this technique, each subject gives multiple referrals, however, only one or two subjects are recruited from each referral. Moreover, this sampling technique can be extensively used for conducting qualitative research, with a population that is hard to locate. Thus, the choice of a new subject depends on the nature of the research study (Wordpress, 2017). This method is more directed and purposeful than most other non-random sampling techniques, such as convenience sampling that focuses only on the most easily identified and reachable members of a population (Verma et al, 2016). Further, the researchers set criteria in the selection of participants such as (a) He/she must be at least eighteen years old and above, (b) an Out-of-School Youth, (c) a resident of Cabarroguis, Quirino and, (d) willing to share his/her life stories.

Moreover, the researchers sent a request letter to the office of the Campus Guidance Counselor to gather data on the number of dropouts and to ask for a referral for the possible subject of the study. In the same way, the researchers also sent letter requests to the Provincial Social Welfare and Development Office (PSWDO) and the Department of Education (DepEd) Division Office for referrals of possible participants. PSWDO only gave data on Children In Conflict With the Law (CICL) and upon scrutiny of their profile, most of them were dropped out from different schools, thus, referrals were given. Likewise, the referred participants were also asked for a referral for further exploration of the possible subject of the inquiry. From the referred subject of the study, the researchers only identified 8 participants who were assumed to be the most qualified subject as stipulated in the criteria. At the onset of the research, there were only five (5) participants who willingly responded to be a part of the study especially during the series of the face-to-face interview. The reasons for those who declined were that they are ashamed of facing teachers and new faces, they do not want to be exposed, and have no time for the activity.

On the other hand, the study was conducted in the province of Quirino, Philippines. The province is located in the Northern part of the Philippines particularly Cagayan Valley, Region 02. Among the provinces of Cagayan Valley, Quirino is the youngest and consists of six municipalities, namely: Diffun, Cabarroguis, Saguday, Aglipay, Maddela, and Nagtipunan. We have chosen Cabarroguis as the setting of our inquiry considering that it is where the university (Quirino State University) we are working with is situated. Indeed, the participants are from the 
different barangays of the municipality. Hence, among the five (5) participants, two (2) of them were from Barangay Gundaway who dropped from school during their Senior High School, one (1) from Barangay Del Pilar who was a former student of Quirino State University and who was dropped out during his freshman college year, one (1) from San Marcos, and also one (1) from Zamora who get out from school during their junior high school year. The three (3) participants who declined from the interview process were from the same barangays and nearby barangays.

\section{Data Collection}

Source triangulations were used to gather data such as in-depth interviews, observation, and document analysis. As posited by Patton (1999), triangulation is a strategy of using multiple methods or data sources to understand better the phenomenon. On the other hand, according to Taylor, Bogdan, \& DeVault (2016), "Triangulation is often thought of as a way of checking out insights gleaned from different informants or different sources of data. By drawing on other types and sources of data, observers also gain a deeper and clearer understanding of the setting and people being studied" (pp. 93-94), to wit:

An open-ended interview was used to gather information regarding the life history and hopes of the participants. The process of the interview was based on the model developed by Siedman (1998). According to Siedman, an in-depth phenomenological interview allows the interviewer and participants to understand the experiences in the right context; and allows the participant to recall the meaning and essence of their experiences (Stage, 2003).

Observation is a technique for obtaining the real picture of the phenomenon under study (Creswell, 2013; Lumpkin, 2002). This process allows the researcher to gain direct information from the source. It also allows the interviewer to understand the context of the phenomenon through direct observation.

Analysis of Documents was also one of the processes of gathering the data. Participants were required to write a journal or prepare a diary in which they expressed their life stories and their hopes. This document was analyzed holistically by the researcher.

\section{Data Analysis}

The narratives of the participants were transcribed holistically. This study employed Polkinghorne's paradigmatic mode of analysis. This mode of analysis relies on paradigmatic cognition, a thinking skill that we humans primarily use to organize experience as ordered and consistent while attending to its general features and common categories and characteristics. A paradigmatic model of knowing is an effort to classify such general features into different categories. It attempts to fit individual details into a larger pattern. Moreover, the analysis also highlighted discussions and reflections of direct sense perception and experiences of the researched phenomenon.

Thus, the description of categories was carefully done by looking closely at the relationships of several categories to reveal common ideas found in various sources of data. As such, general knowledge was generated from the set of data extracted from the collection of stories (Kim, 2016).

Hence, the study divided the timeline into two, namely: During the Participants' stay in School, and After the Participants' Dropped Out from School. To organize the data, the researchers adapted the strategy of Richmond (2002) employing a story map with three categories in two time zones. This strategy helped the researchers analyze the data horizontally and vertically. Subsequently, common themes or salient constructs were extracted as shown in Figure 1 which is the story map used in the study. 


\section{Figure 1}

Story Map of the Participant's Life Stories and Hopes

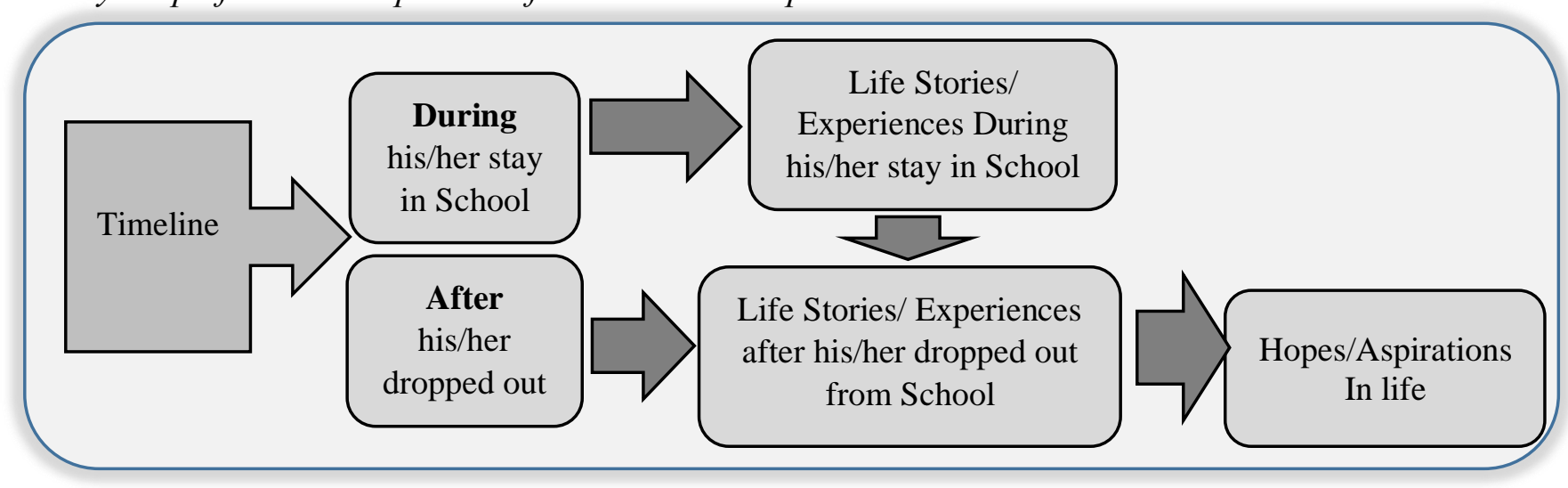

Ethical Protocol

Three ethical issues were considered in this study. These included informed consent, the confidentiality of information given, and the researcher's roles and responsibilities. Informed consent was vital to establishing trust and confidence between the researchers and the participants. The authors explained well the nature of the study and the expectations associated with their participation. Part of this ethical duty is to ensure that the young people's participation in the study was purely voluntary. The use of force, coercion, and intimidation was never employed as these are manifestations of gross disrespect to the fundamental rights of others.

Likewise, consent from the participants was obtained prior to the study. In the absence of an established research ethics review board of the campus at the time of the study, the authors took the initiative to observe all ethical principles in conducting empirical studies. As such, they were strictly guided by the three universally accepted ethical principles: respect for persons, beneficence, and justice. To comply with these principles, research participants were oriented with the utmost respect and without deception as to the scope of the information to be obtained. Also, the consent form was an integral part of the orientation before any data collection procedure was carried out.

The confidentiality of information provided by the participants was taken seriously. Pseudonyms were used to protect the identity of the participants. No names of persons, places, and events were used without the permission of the participants. The authors recognized that it was their role to protect the participants from any physical, emotional, or psychological harm. The participants were given the chance to discontinue if they feel uncomfortable with the research process.

\section{Result}

This study explored the experiences of the Out-of-School Youths (OSYs) during their schooling and after dropped out from school. Empirical data were gathered and thematically analyzed. Hence, the following are the themes generated from the data gathered: 


\section{Table 1}

Themes Generated from the Empirical Data Gathered

\begin{tabular}{|c|c|}
\hline \multicolumn{2}{|c|}{ A. Lived-experiences of the Participants during their Stay in School } \\
\hline $\begin{array}{l}\text { Theme \#1. Struggle to Live and to } \\
\text { Survive }\end{array}$ & $\begin{array}{l}\text { - The participants struggled much on their } \\
\text { allowances and other basic needs in school to } \\
\text { survive. Thus, financial constraints are the main } \\
\text { reason why some of them dropped out of school }\end{array}$ \\
\hline Theme \#2. Push, pull, and fall out & $\begin{array}{l}\text { - The influence of friends pushed and pulled the } \\
\text { participants to deviate from school activities. } \\
\text { - Tried to come back to school but failed to survive } \\
\text { and eventually fall out of school due to habitual } \\
\text { absences. }\end{array}$ \\
\hline $\begin{array}{l}\text { Theme \#3. Bully and bullied: } \\
\text { Blended }\end{array}$ & $\begin{array}{l}\text { - Most of the participants were bullied by their } \\
\text { classmates and by their teachers as well. } \\
\text { - Some of them are bully and bullied as well. Thus, } \\
\text { blended situations arise. }\end{array}$ \\
\hline Theme \#4. Lone, Low, and Leave & $\begin{array}{l}\text { - Being alone triggered the participant's low self- } \\
\text { esteem and eventually decided to leave or drop } \\
\text { from school. }\end{array}$ \\
\hline \multicolumn{2}{|c|}{ B. Lived experiences of the Participants after dropped out of school } \\
\hline Theme \#1. Home, Haze, and Bored & $\begin{array}{l}\text { - As shared by the participants staying home doing } \\
\text { repetitive tasks hazes and that causes boredom. }\end{array}$ \\
\hline Theme \#2. Easy go lucky & $\begin{array}{l}\text { - The participants took no school responsibilities } \\
\text { and take whatever it comes. }\end{array}$ \\
\hline \multicolumn{2}{|l|}{ C. Hopes and Dreams of the OSY } \\
\hline $\begin{array}{l}\text { Theme \#1. Hope for Education and } \\
\text { Employment. }\end{array}$ & $\begin{array}{l}\text { - The participants still wanted to go back to school. } \\
\text { They hope for another chance. } \\
\text { - One of the participants also wanted to have at least } \\
\text { employment for them to survive. }\end{array}$ \\
\hline $\begin{array}{l}\text { Theme \#2. Hope for the Revival of } \\
\text { their Sense of Pride and } \\
\text { Self-esteem. }\end{array}$ & $\begin{array}{l}\text { - The participants desired for their better self and } \\
\text { revived personality. }\end{array}$ \\
\hline $\begin{array}{c}\text { Theme \#3. Hope for Support and } \\
\text { Assistance }\end{array}$ & $\begin{array}{l}\text { - Participants aimed for educational support and } \\
\text { assistance from family and other } \\
\text { organizations. }\end{array}$ \\
\hline
\end{tabular}

\section{Discussion}

Dropping out from school continues to be a phenomenon in Philippine education although every year the government through school authorities dovetails efforts to drumbeat the importance of education in human life. Every school year, reports showed incidences of dropouts among students especially in rural areas, and these dropouts who are lacking in saleable skills end up as nonfunctional and unproductive manpower in the society.

This study reconnoitered the experiences of the OSYs during their schooling and after they dropped out from school. As such, vivid pictures of the participants' life stories were unleashed. The anonymity of the participants was considered using Pseudonyms. The participants' age, place, and basic background of the participants were included in the presentation with their permission. Hence, a few excerpts from the interviewee were quoted to provide empirical flavor to the paper. 


\section{A. Life Stories of the Participants during his/her Stay in School}

\section{Theme \#1. Struggle to Live and to Survive}

The theme reflects the condition of challenges to fight for survival. The face of poverty pushed the participants to struggle for education.

The context of the mentioned theme is related to the life stories of the participants. One of them is named Renan (not his real name), male and 20 years old. A former student of Quirino State University, Cabarroguis Campus, stopped studying during his first year of college. His mother is a plain housewife and his father is a carpenter. According to him, oftentimes when he was still studying, his allowance was just enough for his transportation from their barrio to school. He usually attends his classes empty stomach. So, he even begs for a snack and sometimes his classmates shared him a lunch. The scenario eventually affects his attendance and performance. So, Renan tried to look for a part-time job to live and to survive. Indeed, he was hired as a service crew in one of the fast foods in Santiago City. So, he worked and at the same studying. He was able to survive for the last two months but not until his shift was scheduled during the daytime. As a result, he dropped all his subjects and chose to work. $\mathrm{He}$ reiterated that he needs to live and to survive from scarcity and survive to live for his ambition. This reality was articulated by the participant, as follows:

It is really hard to be poor. There were times that I went to school empty
stomach. I can't do anything anyway but drop from school because my
parents really struggling with our financial needs. I tried actually to
work while studying. At first, I was able to go to school while working
but not when my schedule shifted to the daytime slot. So, I dropped from
school and decided to work to save the amount for my future schooling.
Besides, I don't have any other choice. Anyway, there is no age limit in
taking a college degree. In fact, I have a classmate who is 26 years old
and he is still in his first year of college ... I have to endure and save for
my ambition. I hope I can... but I can do it!

The aforementioned context is supported by the point of view of Munoz (2010). He reiterated that poverty erodes the quality of life and reduces access to education and other services. As mentioned by Rock et al (2016), poverty endangered the social well-being of youth living in extremely rural communities. The poor which are less organized have more difficulties of access. Additionally, Concepcion (2012) assumed that, in effect, the lack of power of the poor makes them easily ignored, and as a result, they have little say in the decisions that affect them particularly in changing their lives for the better. Moreover, financially weak students have a high possibility of dropout (Smith, 2005) as cited by (Latiff, 2015).

Thus, financial issue is the greatest factor that could lead to dropouts among high school and college students. The case of Renan is an objective and reality-based situation where the participant showed persistence to live and to survive for his ambition. A reflection of an ambitious yet goal-oriented individual.

\section{Theme \#2. Push, Pull, and Fall Out}

The theme figures the pressure causing dropout of school. Exposure to peer antisocial initiatives distracts students from pursuing school. Demotivated students then tend to fall out of school.

The theme is connected with the narratives of the participants and it is specifically related to the life story of Ricky (not his real name). He is 18 years old. His mother is an 
Overseas Filipino Worker (OFW) and his father is a driver of a Public Utility Vehicle (PUV). He is passionate about the motorbike. His desire and passion pushed him to do unscrupulous acts and pulled by his environment (friends) to do more complicated acts, and ultimately fell out of school. According to him, he was also influenced by his friends in stealing gas from the motorcycles parked along the highway and until not only gas but even motorcycle parts and eventually different vices like drinking liquor and smoking. This life story of the participant can be portrayed in the following statements:

\begin{abstract}
Having a motorbike has been my dream for a long time. I forced Papa to tell Mama to buy my dream motorbike. That's it, Papa bought it. At first, I went to school very early because I have already my own ride. But not until my friends encouraged me to go out from school for joyriding...until I prioritized driving motorbike and sacrificed my schooling. My teacher called my attention to drop me out of her class.
\end{abstract}

He also added that:

The bad thing was that, my friends taught me not only how to drink alcohol but also how to steal gas. What we do, we stole gas from those parked motorcycles in the street or anywhere. The worst thing was that we came up with that point of not only stealing gas but also motor parts that we like. We took away motorcycle parts from those parked in the street and sell or use them on our own. The last time we stole motor parts was when one of my friends caught us in the act, so we were imprisoned for three days... and was settled because my Papa paid it. It's embarrassing but you know, February 12, 2018, is a memorable date for me because that was the date when I experienced for the first time being beaten by Papa... now I have stopped studying. They no longer enrolled me in college. Anyway, never mind...

The scenario mentioned above is articulated in the context posited by the National Center for School Engagement (2018) in their article "Youth out of School: Linking Absence to Delinquency". NCSE echoed that unexcused absence is the first symptom that a student is likely to be at risk. If they are not in school, they are not learning and consequently fall behind in their studies. Also, Altinkurt (2008) stated that trying to be accepted by friends, the pressure of friends who are truant, and wanting to go to internet cafes have a highly significant effect on the absenteeism of students from school. In addition, Watt \& Roessingh (1994) mentioned another factor called falling out of school, which occurs when a student does not show significant academic progress in schoolwork and becomes apathetic or even disillusioned with school completion. According to Battin et.al (2000) as stated by Wallace (2016), some general deviancies that students may face include violence and disruptive behavior when they are out of school. When students fall behind at school it may be difficult, perhaps impossible, to make up lost ground and "catch up". This leads to disengagement from school and teachers and can ultimately lead to serious anti-social behavior like juvenile delinquency.

Indeed, schools typically discipline students' misbehavior by suspending them. On the other hand, some parents used to give the luxuries of their children that sometimes leading to misbehavior. These scenarios send a message that the "push-out" model of discipline tends to make a bad situation worse. By definition, at-risk youth are already likely to be involved in several risky behaviors, and the elimination of a structured school day, including having extra free time, perpetuates these behaviors. 
Therefore, Schools must be aggressive in their efforts to eliminate truancy instead of perpetuating it. Also, parents should give the best guidance and supervision of their children to avoid such behavior and eventually lead them to a better future.

\title{
Theme \#3. Bully and Bullied: Blended
}

Students' involvement in bullying varies across roles and over time. A student may be victimized by classmates but bully a sibling at home. Bullying is a complex form of interpersonal aggression that can be both a one-on-one process and a group phenomenon. It negatively affects not only the victim but the bully and witnesses as well. Thus, most of the time the participants were bullied by their classmates and on the contrary, the bully was also bullied. Two of the participants admitted that they were the inheritor of bullying in school, but guilty of behaving badly. One of the participants named Billy (not his real name), a 19-yearold male participant. His mother is a teacher and his father is a farmer. Stopped and did not enroll in college. He explained that he got in trouble "for stupid things," but he said it was mostly because he was "in the wrong place at the wrong time." He said, his friend was actually doing the trouble but always point to him the act. Billy showed disappointment that once he got in trouble, the administration continued to characterize him as a problem. He described what amounts to a self-fulfilling prophecy; the school believed he was a troublemaker, so he behaved like one. Billy specifically shared that:

In school, my teacher always blames me for all the wrongdoings of my classmates even if I didn't. I am always the primary suspect... eh I just get involved because of my classmate's stupidity... My teachers do not believe in me and no longer trust me. That is the reason why my parents decided not to allow me to enroll this semester because they assumed that I will just be doing nonsense. It seems to be crazy but sober somehow, so I just accepted that I will stop studying...

Similarly, Tantan (not his real name) 18 years old, a Junior High School dropped out. His parents established a buy and sell business (vegetables and fruits). He described getting in trouble as "so easy over there and over nothing." He said he got in trouble with a very simple problem as he considered as a routinary and habitual dialogue of his teacher every time he saw him like "take your hat off" and "You are not in proper uniform again!", "Where is your ID, wear it properly!" Such sounds according to him are not pleasing to his ears and prevent him from attending his class. Until he was suspended that caused him to miss class time. He stated that missing class time affected him to fall behind with his classwork, ultimately making it very difficult for him to recover academically, and eventually gave up hoping for success in high school. He verbally shared that:

\begin{abstract}
Habitual improper wearing of school ID and uniform! This was the context of the letter from the guidance office given to my parents. I was suspended for one week I think, in fact, I can still remember I was wearing a uniform and ID. May I ask you, do I not have the right to do what I want without such heavy disobedience. I don't know why Mam__ is always mad at me. He always bullied me. Mam is also different (sarcastic smile).
\end{abstract}

The foregoing context was supported by the study conducted by the researchers at the Institute of Education in London as cited by Bloom (2008). They found out that less than 10\% of the junior high schools are "true bullies". On the other hand, the reported influence of dropout 
factors has shifted toward teacher factors, primarily because they could not get along with teachers and could not get along with students because they look at them as stressors or bullies. Perhaps a climate of such high expectations has led more dropouts to the point of exasperation and in turn to quit school. As mentioned by Lamote (2013) and Strand \& Granlund (2014), the sense of belonging to the school, trust in the school, trust in the staff, commitment to various school activities decrease absenteeism rates, the negative aspects of the school setting may cause stress in students and lead to dropout. Moreover, Jordan (1994) explained pressures on teachers and peers' factors. A student is forced to get out when adverse situations within the school environment lead to consequences, ultimately resulting in dropout. Thus, teachers should also look into the real reason why these students misbehave in class. Scanning on their profile probably helps the teacher in understanding better their personality and eventually apply a better approach of disciplining them.

\section{Theme \#4. Lone, Low, and Leave}

Disengagement from others is boring to some students and caused a negative impact in their academic performance. Such experience sometimes leads to a lack of interest and eventually leaving school.

Students may be identified as being at risk if they are experiencing academic failure (Aron, 2006). The context of the abovementioned theme is reflected in the life stories narrated by most of the participants. The majority of them (Ricky, Billy, and Nanu) shared that they encountered problems, particularly in their academic performance. Specifically, Nanu (not his real name) 18 years old and dropped out of school during his Junior High School year. His mother is a plain housewife and his father is a farmer. He said that he incurred failing marks in most of his subjects. He described himself as a loner and ashamed of seeking help from his classmates. As such, because he is not confident enough, he got a very low grade, and that caused him to leave out from school.

He verbalized that:

I am not friendly actually sir. I feel ashamed sometimes because I feel
like they are different... I don't know, no matter what I do reading,
nothing really enters my brain. I was embarrassed when mam
announced the score because I got the lowest... My parents are angry,
especially papa. so, I was forced to drop out of class...! It is useless for
me to always be in school because my grade is completely failed.

The foregoing scenarios contextualized that some of the students are forced to drop out of the school system because of their low performance and discrimination. Some have study skills problems and cannot follow class lessons. Indeed, these claims were supported by Bridgeland, Dilulio, Morison, 2006; Council on Virginia's Future, 2009; The High School Student Engagement Study, 2010; Levin \& Arafeh (2002) and Rothman \& Mizrahi, (2014) in their reports focusing on a variety of reasons leading to a student's decision to drop out of high school. On the other hand, Thornton et al (2013) said that participation in parent-teacher meetings and other activities, monitoring the child's school attendance and homework supports the child's academic progress and school attendance. They iterated that lack of connection to the school environment, a disconnect between student characteristics and school instruction, a perception that school is boring, motivation issues, academic challenges, and the weight of realworld events are the reasons for leaving the school. Indeed, the school environment is assumed to be one of the factors that lower their self-esteem and eventually prompts them to drop out of school before completing their compulsory or basic education. Thus, the teacher must be very 
sensitive on how the learners capture the learnings they wanted to be retrieved by their students. In that way, a pleasing and positive environment will be established.

Therefore, responsive teaching cannot be produced through a regulated curriculum. To create bridges between challenging curriculum goals and individual student experiences and needs, teachers must be flexible to develop learning engagements that accommodate a variety of cognitive styles, with activities that broaden rather than reduce the range of possibilities for learning (Noddings, 2005). At the same time, teachers must consider the physical, affective, and emotional needs of their students as well as be concerned with moral and spiritual outcomes.

\section{B. Life Stories of the Participants after his/her Dropped out from the School}

\section{Theme \#1. Home, Haze, and Bored}

Lack of interest in repetitive tasks at home stimulates loneliness and boredom. Students who are unable to articulate their wants and needs have difficulty in describing their inner feeling.

Some of the participants stayed at home after they dropped out of school. They said their life is somewhat hazed as it darkens their right to socialize themselves. They were directed by their parents to do some household chores and eventually, the participants said they feel bored of their routine. As such, negative impact is very evident as it showed retaliation on the activities given to them: One of the participants articulated that:

I am bored here at home. I want really to enroll but Mama and Papa don't want to it. They told me that they will allow me if I will change my way of living and focus on my studies. Maybe next year according to them...

Thus, such a scenario indicated above projects dissatisfaction. As stated by Thornton et al (2013), families may prefer not to send their children to school because of several reasons such as going shopping, funerals, weddings, or going out of the city or district. Also, according to Pickhardt (2012), adolescence is driven by dissatisfaction, the young person no longer content to be defined and treated as a child anymore, wanting to become older but not sure how, more boredom part of the price they pay for the uncertain developmental journey they now undertake - having more times of not knowing what to do with themselves. He also reiterated that more than ever before the young person wants the freedom to be independent, but what he or she discovers is that freedom is one birthplace of boredom. Now that you have more choice, what are you going to do with it? In many cases, the adolescent simply doesn't know. The past is much clearer ("How I don't want to be any more") than the future ("How I want to be instead.") So rather than feel excited, the teenager feels at a loss to know how to fill the void of opportunity that has been created.

\section{Theme \#2. Easy Go Lucky}

A student who does not think and plan for the future and takes whatever it comes without worrying is considered easygoing.

One of the participants shared that he is contented and happy after he dropped out of school. His father allowed him to do what he wants but did not allow him to enroll in the meantime. He verbalized that: 
I'm okay. Now that I am not enrolled, I can do what I want. Sleep and wake up without worries. My Papa said I would enroll later. I know he is still mad at me because of what happened before I was dropped... I like the routine anyway. Feeling lucky...

Thus, Borba (2017), said that spoiling a child is rarely a parent's goal, but is easy to do. She pointed out that allowing our children to do what they want even it is not acceptable increases unpleasantness. They are usually turned off by their bossy and selfish behaviors.

On the other hand, adults don't like their often rude and excessive demands lowers persistence. Things come a bit easier and spoiled kids are used to getting their way, so they often have a tougher time with life's downsides and give up quickly. Moreover, self-centered individuals have a higher likelihood of troubled relationships, depression, anxiety, and lower self-esteem. Reduces satisfaction and appreciation. Getting "too much" can make a child perpetually unappreciative and become a chronically dissatisfied adult.

\section{Hopes and Aspirations of the Out of School Youths}

The results from the narratives of the participants show the existence of a gap between participants' aspirations for higher education and their actual chances of accessing this level of education. Thus, this section of the paper presents the hopes of the Out-of-School Youths.

\section{Theme \#1. Hope for Education and Employment.}

Hope leads to academic triumph and substantial rewards await for those who make the hard works and efforts.

Although it is very evident that the participants have different life stories, it can be gleaned that they have the same hope and ambition to finish their education and get a stable job.

Indeed, despite their negative experiences along the way of their formal education, the participants still hoping and had a positive outlook in life and believed that through education, they can improve their quality of life. That they could get a decent job and receive enough salary to address their basic needs and that of their family.

As Renan mentioned:

\section{I have to endure and save for my ambition. I hope I can... but I can do it!}

Moreover, they aspire for help as a realization of their dreams. Renan for example has the motive to survive from scarcity and the motive to live for his ambition. These hopes drive him to a positive outlook and hopeful that one day soon he will be able to achieve his goal.

Thus, the hope of the participants mentioned supports the findings of previous studies regarding the existence of high educational aspirations among low-income young people and the fact that education is highly valued by OSYs and their parents as well (Benavides et al, 2005; Boyden, 2013; Crivello, 2011). Additionally, Manning (2016) believed that all educators must revisit schooling practices in ways that both affirm students' knowledge, perspectives, community realities, and life goals. 


\section{Theme \#2. Hope for the Revival of their Sense of Pride and Self-esteem.}

Hope demonstrates better personality, students who are full of hope have a lower level of depression and have feelings of self-worth.

Most of the participants shared that they want to revive their sense of pride, responsibility, and self-esteem. They are hoping that one day soon they begin to feel proud of themselves because they have acquired the functional knowledge which will make them useful members of the community. They assumed that increased self-esteem characterized by an increased self-confidence and optimism can boost their morale whom they used to believe that they are lower than most people in terms of education and social status. On the other hand, the participants tried to cope up with these challenges hoping for the better.

Ricky shared that:

Most of the time other people looked at me like an antagonist. On the other hand, I tried to be as good as I can but because of the influence of the environment, I usually get out from the right lane. But I will try to be a better person.

Kinloch (2017) stated that in the design of student's learning and opportunities, educators must recognize the power and potential of student achievement in their communities. Moreover, Rogers (1961) explained self-esteem in terms of the disparity that exists between the ideal self and the real self and viewed the social world as the source of ideas and knowledge (ideal self) against which the individual evaluates his/her actual performance and thus his/her level of self-esteem is determined. He suggests that any maladjustment is due to the difference between the two. Vygotsky (1978) viewed the role of the social world as the source of the child's ideas and views the cultural world as a stimulus the child will experience and internalize as the criteria against which his/her actions are evaluated and his/her level of self-esteem is determined.

Thus, the two participants (Ricky and Billy) tried to accept who they are now but they are hoping that one day soon their family and the community will see them not as a threat but as a productive Out-of-School Youth and hope for coming back to school.

\section{Theme \#3. Hope for Support and Assistance.}

Out-of-school-youth wishes for hope and a future. Through kindness and collaboration of partner organizations, security for education provides a better life for them.

At present, the participants do not enjoy any programs along with educational pursuits. Thus, they hope for looking at the aspect of functional knowledge. They seek the basic competencies and literacy skills needed for them to function in the community which in turn develop their self-concept: the way they look and value themselves.

I did not avail of any educational assistance but I want to learn. In the future, maybe there's an opportunity.

Further, they looked at education as the key for personal empowerment and a tool for success in both personal, social, and economic aspects and provided them an opportunity to create a positive change in their life and alleviate themselves from poverty, take charge of their own lives, make a sound decision, plan for the future, owe responsibility for their actions and eventually be of help to other people in the community and the society. 
According to the Philippine Out-of-School Children and Youth Development (POSCYD), deprived of completing high school education, the out-of-school youth are further marginalized from acquiring technical skills.

Thus, the continuing inability of many poor young people to complete basic education and/or undertake technical education, consign them to the vicious cycle of poverty. Their lack of education constrains their access to better-paying jobs or ability to succeed in entrepreneurial pursuits, all of which require a higher degree of literacy. Workers with a solid foundation in technical education, have better chances of landing jobs.

\section{Conclusions}

The primary intent of this study is to capture the life stories and hopes of the Out-ofSchool Youth. In conclusion, the Out-of-School Youths' life stories significantly reflected the realities of life.

Indeed, it was captured from the participants' stories during their stay in school that they struggled to live and to survive. On the other hand, one of them said that his vicious material inclination pushed, pulled, and fell him out of school. The OSYs also experienced being a bully and to be bullied. They also shared that because of being alone and have low self-confidence they felt that they are not competitive enough in their academic performance and eventually fell out or left the school.

Likewise, their stories after their dropout dramatically noted as the participants articulated that they still prioritize their living as they work for self-survival. They also shared that they feel bored and some of them even said that they have contended and happy staying outside the school.

Furthermore, the paper also highlighted the hopes of the participants such as hope for education and employment, hope for the revival of their sense of pride and self-esteem, and hope for support and assistance.

These findings coincided with educational changes, such as the standards movement in education, as well as social movements and cultural changes, including individuals' rights, civil rights, dual-income families becoming the norm for many families, and the strong impact of inflation on the need for employment. Partly as a result, it became an essential rite of passage for all adults to have stable work, and school completion guaranteed a higher wage and opened doors to higher educational institutions. Still, the dropout problem has persisted through these changes even amid higher rates of school completion; moreover, it is still found in alarming rates in many culturally and linguistically diverse groups like Filipinos.

Indeed, understanding the practical reasons for early school leaving is desirable. Its emic perspective may provide a piece of better knowledge on students' educational needs and eventually help to improve teaching and administrative practice.

Concomitantly, the themes and patterns that emerged from the narratives and hopes of the OSYs may help teachers and administrators in deciding which courses of action to follow and ultimately develop more comprehensive student retention programs. Also, a significant closing note, as well as implication for this manuscript, is the direction of future practice. And hope that the reflections, insights, and stories shared in this report will help transform how we view these young people - not as problems to be solved, but as a potential to be fulfilled.

Moreover, it was also noted possible intervention in answer with the hopes and aspirations of the participants, the researchers initiated the following initial programs, as (1) organization of Parent Teachers Association, (2) collaboration with the PSWD, DTI, and TESDA (3) collaborative extension programs between and among the different departments of the university.

Thus, the study on the life stories and hopes of the Out of School youths played a potent significance to the teachers, parents, and the university system as a whole. Through this paper, 
we were able to understand the complex world of the Out-of-School Youths. We should take students' perceptions seriously and observe our teaching practices and consider our intent on creating an all-encompassing learning environment.

\section{Funding Details}

This work was supported by the Quirino State University particularly the Office of the Campus Research and Development.

\section{Disclosure Statement}

This is to acknowledge any financial interest or benefit that has arisen from the direct applications of your research.

\section{References}

Altınkurt, Y. (2008). Öğrenci devamsızlıklarının nedenleri ve devamsızlığın akademik başarıya olan etkisi. Dumlupınar Üniversitesi Sosyal Bilimler Dergisi, 20, 129-142.

Aron, L. (2006). An overview of alternative education. Urban Institute, page 44. https://eric.ed.gov/?id=ED500807

Battin-Pearson, S., Newcomb, M., Abbot, R., Hill, K., Catalano, R., \& Hawkins, J. (2000). Predictors of early high school dropout: A test of five theories. Journal of Educational Psychology, 92(3), 568-582. doi:10.1037/0022-0663.92.3.568

Benavides, F. G., Benach, J., Muntaner, C., Delclos, G., Catot, N., \& Amable, M. (2005). Associations between temporary employment and occupational injury: what are the mechanisms? BMJ Journals. 63 (6). http://dx.doi.org/10.1136/oem.2005.022301.

Benson, P. (2014). Autonomy and independence in language learning. Taylor \& Francis Group: Routledge. 9781315842172.

Bhutta, Z.A. (2017). Losing a generation: The impact of malnutrition. Daily DAWN. Islamabad, Pakistan. https://www.dawn.com/news/ 1296918.

Bhutta, Z.A. (2017). Nurturing care: Promoting early childhood development. The lancet. 389 (10064), 91-102. https://doi.org/10.1016/S0140-6736(16)31390-3

Bloom, D. (2008). The study finds bullies are the bullied too. The Guardians.

Borba, M. (2017). What are some dangers of raising spoiled children? https://www.sharecare.com/health/parenting/dangers-of-raising-spoiled-children

Boyden, J. (2013). We're not going to suffer like this in the mud': educational aspirations, social mobility, and independent child migration among populations living in poverty. Journal of Comparative and International Education. 43 (5), 580600.https://doi.org/10.1080/03057925.2013.821317

Bridgeland, J.M., Dilulio, J.J., \& Morison, K.B. (2006). The silent epidemic: perspectives of high school dropouts. Civic Enterprises, Peter D. Hart Research Associates. page 44. https://eric.ed.gov/?id=ED513444.

Chiangkoon, W. (2009). Thai education state in 2007/2008: Equity and quality problems of education [online]. http:// witayakornclub.wordpress. com

Christenson, S.L., \& Thurlow, M.L. (2004). School dropouts: Prevention considerations, interventions, and challenges. Curr Dir Psychol Sci. 13:36-39

Clandinin, D. J. (2010). Potentials and possibilities for narrative inquiry. IAP Information Age Publishing (p. 1-13).

Clandinin, D. J., Huber, J., Huber, M., Murphy, M. S., Murray-Orr, A., Pearce, M., et al. (2006). Composing diverse identities: Narrative inquiries into the interwoven lives of children and teachers. Routledge. 
Concepcion, G., Peria, E., \& Clarete, R. (2012). The role of science, technology, and research in economic development. https://ovpaa.up.edu.ph/wp-content/uploads/2015/05/TheRole-of-Science-and-Technology-in-Economic-Development

Council on Virginia's Future (2009).

Creswell, J. (2007. Qualitative inquiry and research design: Choosing among five approaches ( $2^{\text {nd }}$ edition). SAGE Publication India.

Creswell, J. (2013). Research design: Qualitative, quantitative, and mixed methods approaches. Sage.

Creswell, J. \& Poth, C. (2017). Qualitative inquiry and research design: choosing among five approaches. Sage.

Crivello, G. (2011). Becoming somebody': Youth transitions through education and migration in Peru. Journal of Youth Studies, 14 (4), 395-411. https://doi.org/10.1080/13676261.2010.538043

Damgaci, F. \& Aydin, H. (2018). What we can learn about multicultural education from social media. EURASIA Journal of Mathematics, Science and Technology Education, 14(3), 797-810.

Demir, K. \& Akman Karabeyoglu, Y. (2015). Factors associated with absenteeism in high schools. Eurasian Journal of Educational Research, 62, 37-56. http://dx.doi.org/10.14689/ejer.2016.62.4.

Fernandez, R.C. \& Abocejo, F. (2014). Child labor, poverty, and school attendance: Evidences from the Philippines by region. CNU Journal of Higher Education, 8, pp.114-127. https://www.researchgate.net.

Franzosi, R. (2010). Quantitative narrative analysis. SAGE Publications, Inc. ISBN 978-14129-2525-9.

Freebody, P. (2003). The nature of teachers' qualitative judgments: A matter of context and salience. Australian Literacy Educators' Association.https://search.informit.org/doi/epdf/10.3316/ielapa.146420444161811

Gleason, P. \& Dynarski, M. (2009). Do we know whom to served? Issues in using risk factors to identify dropouts. Journal of Education for students placed at risk (JESPAR), 25-41. https://doi.org/10.1207/S15327671ESPR0701_3.

Hatch, J.A. (2002). Doing qualitative research in education setting. State University of New York Press. ISBN 0-7914- 5503-3

James, G. (2018). A narrative inquiry perspective into coping mechanisms of international postgraduate students' transition experiences. American Journal of Qualitative Research, 2 (1), 41-56. http://www.ajqr.org/A-narrative-inquiry-perspective-intocoping-mechanisms-of-international-postgraduate, $91850,0,2 . \mathrm{html}$.

Johnson, J. K. (2013). Model exploration of teacher efficacy, attitudinal beliefs, and caring behaviors towards Latino linguistically diverse students. University of Northern Colorado Scholarship \& Creative Works @ Digital UNC. page 179.

Jordan, W. J., Lara, J., \& McPartland, J. M. (1994). Exploring the complexity of early dropout causal structures. Center for Research on Effective Schooling for Disadvantaged Students, The John Hopkins University.

Kim, J.H. (2016). Understanding narrative inquiry: The crafting and analysis of stories as research. SAGE Publications, Inc.ISBN 978-1- 4522-8278-7.

Kinloch, V., Burkhard, T., \& Penn, C. (2017). When school is not enough: Understanding the lives and literacies of black youth. National Council of Teachers of English, 52 (1), pp. 3454. https://www.jstor.org/stable/44821286

Klassen, A., Creswell, J.W., Clark, V., Smith, K.C., \& Meissner, H. (2012). Best practices in mixed methods for quality of life research. Quality of Life Research,21, pages377-380. 
Lamote, C., Speybroeck, S., Van Den Noortgate, V., \&Van Damme, J. (2013). Different pathways towards dropout: The role of engagement in early school leaving. Oxford Review of Education, 39(6), 739-760.

Latiff, M.A., Mohamed, W.A., \& Asran, M.A. (2015). implementation of inclusive education for special needs learners with learning disabilities. Procedia - Social and Behavioral Sciences, 204, 81-87. https://doi.org/10.1016/j.sbspro.2015.08.115.

Lavrentsova, L. \& Valkoy, P. (2017). The effects of student-teacher and student-student relationship on school engagement: An empirical research in Bulgaria. Pedagogy. 91 (3). ISSN 1314-8540 (Online) ISSN 0861-3982.

Laya, M.,Rafael, C., \& Solera, R. (2017). Higher education for sustainable development at EARTH University. International Journal of Sustainability in Higher Education. ISSN: $1467-6370$

Levin, D., \& Arafeh, S. (2002). The digital disconnect: The widening gap between internetsavvy students and their schools. American Institutes for Research. Page 38. https://eric.ed.gov/?id=ED471133.

Lexicon.com (2020).

Lichtman, M. (2011). understanding and evaluating qualitative educational research. SAGE Publications, Inc. ISBN 978-1-4129-7526-1.

Lumpkin, P.W., Silverman, W., Weems, S.C., Markham, M., \& Kutines, M. (2002). Treating a heterogeneous set of anxiety disorders in youths with group cognitive-behavioral therapy: A partially nonconcurrent multiple-baseline evaluation. Behavior Therapy, 33 (1), 163-177. https://doi.org/10.1016/S0005-7894(02)80011-9.

Machica, A. I., \& Machica, A. A. (2017). Aspirations of the out-of-school youth: Barangay Napara-an, Salcedo, Eastern Samar perspective. The Qualitative Report, 22(13), 34113430. https://nsuworks.nova.edu/tqr/vol22/iss13/3.

Manen, M.V. (2014). The tact of teaching: The meaning of pedagogical thoughtfulness. Routledge, Taylor \& Francis Group. ISBN 978-1- 61132-943-8.

Manning, L. (2016). Rewriting struggles as strength: Young adults' reflections on the significance of their high school poetry community. Research in the Teaching of English,50, 288-308.

Maynard, B.R., Salas-Wright, C.P. \& Vaughn, M.G. (2015). High school dropouts in emerging adulthood: Substance use, mental health problems, and crime. Community Ment. Health J. 51, $289-299$.

Merriam, S. \& Tisdell, E. (2015). Qualitative research: A guide to design and implementation. Jossey-Bass.

Mughal, A.W., Aldridge, J. (2017). Head teachers' perspectives on school drop-out in secondary schools in rural Punjab, Pakistan. Educ. Stud. 53 (4), 359-376. https://doi. org/10.1080/00131946.2017.1307196.

Munoz, T., \& Amaral, T. (2010). Internet usage for travel and tourism: The case of Spain. Copenhagen, Volume 42.

Naew Na. (2012) 'Out-of-school' children! Time to get around "young criminal" problem. http://www. teenpath.net/ content.asp?ID=12856\#.VYOcCEaMWec.

Noddings, N. (2005). What does it mean to educate the whole child? Educational leadership. 63(1), pp. 8-13. http://citeseerx.ist.psu.edu/viewdoc/download?doi=10.1.1.457.8800\&rep=rep1\&type= pdf

Philippine Out-of-School Children and Youth Development. (POSCYD). (2003). Out-ofSchool Children and Youth in the Philippines: Issues and Opportunities

Pickhardt, C. E. (2012). Aspects of adolescent boredom. Psychology Today. https://www.psychologytoday.com/us/blog/surviving-your-childsadolescence/201208/aspects-adolescent-boredom. 
Provincial Advisory Council (2017). Philippine Information Agency -Quirino. 4Ps Advisory Councils to bring back 826 out-of-school-youth to school. Retrieved from https://pia.gov.ph/news/articles/1003497.

Retrieved from https://openknowledge.worldbank.org/handle/10986/14406

Richmond, H. J. (2002). Learners' lives: A narrative analysis.The Qualitative Report,7(3), 114.

Riessman, C.K. (2008). Looking back on narrative research: an exchange. SAGE.

Riessman, C.K. (2010). Narrative methods for the human sciences. SAGE Publications.

Rock, A., Barrington, C., Abdoulayi, S., Tsoka, M., Mvula, P., \& Handa, S. (2016). Social networks, social participation, and health among youth living in extreme poverty in rural Malawi. Social Science \& Medicine, 170, 55-62. doi: 10.1016/j.socscimed.2016.10.005.

Rogers, C. (1961). On becoming a person: A therapist's view of psychotherapy. Houghton Mifflin Harcourt.

Rothman, J., \& Mizrahi, T. (2014). Balancing micro and macro practice: A challenge for social work. Social Work, 59 (1), 91-93. https://doi.org/10.1093/sw/swt067.

Shernoff, E.S., Kratochwill, T.R., \& Stoiber, K.C. (2003). Training in evidence-based interventions (EBIs): What are school psychology programs teaching? Journal of School Psychology, 41(6), 467-483.

Simic, N., \& Krstic, K. (2017). School factors related to dropout from primary and secondary education in Serbia: A qualitative research. Psiholoska Istrazivanja. XX (1), $51-70$.

Smith, A. (2005). An inquiry into the nature and causes of the wealth of nations. Retrieved from http://glenbradford.com/files/Stocks/wealth-nations.pdf

Stage, F., \& Manning, K. (2003). Research in the college context: Approaches and methods. Routledge.

Strand, A. M. \& Granlund, M. (2014). The school situation for students with a high level of absenteeism in compulsory school: Is there a pattern in documented support? Scandinavian Journal of Educational Research, 58(5), 551-569.

Tafere, Y. \& Pankhurst, A. (2015). Can children in Ethiopian communities combine schooling with work? Young Lives. Retrieved from https://www.younglives.org.uk/sites/www.younglives.org.uk/files/YL-WP141Combining\%20Schooling\%20and\%20Work.pdf.

Taylor, S. J., Bogdan, R., \& Devault, M. L. (2016). Introduction to qualitative research methods: A guidebook and resource (4th ed.). Wiley \& Sons.

Teneva, M. (2018). Dropping out of school. Trakia Journal of Sciences, 4, 302 - 307.

Thornton, M., Darmody, M., \& McCoy, S. (2013). Persistent absenteeism among Irish primary school pupils. Educational Review, 65(4), 488-501.

Tudy, R.A., Niez, A. D., Orion Jr., H. C., Morales, M. E. C., Abear, E. E. A., Rebato, A. H., Placer, E. J. M., \& Leal, M. N. (2017). Employability and the contribution of learned competencies and catholic education in the workplace for the graduates of Cor Jesu College. SLONGAN, 3(1), 21-31.

UNESCO Institute for Statistics. (2018). Education and disability: analysis of data from 49 countries. Montreal, Quebec. NCVER's International tertiary education research database. Retrieved from http://uis.unesco.org/sites/default/files/documents/ip49education-disability-2018-en.pdf

Valkoy, P. (2018). School dropout and substance use: consequence or predictor? Trakia Journal of Sciences, 2, 95 - 101.

Verma, V., Mishra, MV., Mehta, MP. (2016). A systematic review of the cost and costeffectiveness studies. BMJ Open Journal, 122(10), 1483-1501.

Vygotsky, L. (1978). Social Development Theory (L. Vygotsky). http://tip.psychology.org/vygotsky.html. 
Wallace, C. (2016). A high school dropout prevention program for at-risk students. Walden University Scholar Works. Retrieved https://scholarworks.waldenu.edu/cgi/viewcontent.cgi.

Watt, D., \& Roessingh, H. (1994). Some you win, most you lose: Tracking ESL dropout in high school (1988-1993). English Quarterly, 26, 5-7.

Withers, M., Hillman, A. \& Canella, A. (2012). A multidisciplinary review of the director selection literature. Journal of Management, 38 (1). https://doi.org/10.1177/0149206311428671.

WordPress for Beginners 2017: A Visual Step-by-Step Guide to Mastering WordPress.

\section{Notes on Contributors}

Dr. Lauro S. Aspiras is an Associate Professor and currently the Campus Director for Research and Development at Quirino State University, Cabarroguis Campus. He is the Editor of the campus' Multidisciplinary Research Journal. He also authored two (2) textbooks for Senior High School titled "Effective Speech and Oral Communication" and "English for Academic and Professional Purposes". He obtained the degree Bachelor of Secondary Education Major in English and Master of Arts in Education at Quirino State University, Diffun Campus. He finished Doctor of Philosophy in Educational Management at St. Paul University Philippines, Tuguegarao City, Philippines. His research interest are social sciences, language, and educational management. ORCID: https://orcid.org/000-0003-4912-8868,

Dr. Emma D. Aspiras is an Associate Professor and currently the Campus Director for Gender and Development (GAD) at Quirino State University, Cabarroguis Campus. She is also the Program Chairperson of the Master of Management in the graduate school. She obtained the degree Bachelor of Science in Business Administration, Master of Arts in Education (MAED) at Quirino State University, Diffun Campus. She finished Doctor of Philosophy in Educational Management at St. Paul University Philippines, Tuguegarao City, Philippines under the CHED K-12 Scholarship Program. Her research interests are social sciences, gender and development, and educational management. ORCID: https://orcid.org/000-0003-47824325, E-mail; emma.aspiras@qsu.edu.ph.

Manuscript received March 31, 2021

Final revision received May 13, 2021

Accepted May 14, 2021 